\title{
Tympanomastoidectomy: Comparison between canal wall-down and canal wall-up techniques in surgery for chronic otitis media
}

\author{
Alexandre Fernandes de Azevedo', Anna Bárbara de Castro Soares², Henrique Queiroz Correa Garchet ${ }^{3}$, \\ Nicodemos José Alves de Sousa4. \\ 1) MD in Infectology at the Federal University of Minas Gerais. Assistant Doctor - Otolaryngology Clinic of Santa Casa B.H \\ 2) Resident of Plastic Surgery at the Hospital Mater Dei \\ 3) Resident of Otolaryingology at the Santa Casa B.H. \\ 4) M.D. in Otolaryngology at the Federal University of São Paulo. Honorary Chief of the Otolaryngology Clinic of Santa Casa B.H \\ Institution: Santa Casa of Belo Horizonte \\ Belo Horizonte / MG - Brazil. \\ Mailing address: Clínica de Otorrinolaringologia da Santa Casa de Belo Horizonte - Alexandre Fernandes de Azevedo - Rua Perdigão Malheiro, $195 / 501$ - Cidade Jardim \\ - Belo Horizonte / MG - Brazil - Zip code: 30380-050 - Telephone: (+55 31) 8863-8548 - E-mail: xandefa@ hotmail.com \\ Article received on September $2^{\text {nd }}, 2012$. Article accepted on April $15^{\text {th }}, 2013$.
}

\section{SUMMARY}

Introduction: Chronic otitis media (COM) is an inflammatory condition associated with otorrhea as well as large and persistent perforations of the tympanic membrane in some cases. COM can also lead to cholesteatoma. Surgical treatment with canal walldown and canal wall-up tympanomastoidectomy is considered for both types of illness. The choice of technique is controversial and is dependent on several factors, including the extent of disease.

Objective: We aimed to evaluate surgical outcomes in COM patients with and without cholesteatoma treated with canal walldown and canal wall-up tympanomastoidectomy. Disease eradication and post-operative auditory thresholds were assessed. Method: Patient records from the otorhinolaryngology department of a tertiary hospital were assessed retrospectively.

Results: Patients who underwent canal wall-up tympanomastoidectomy had a higher rate of revision surgery, especially those with cholesteatoma. However, there were no statistically significant differences in post-operative hearing thresholds between the two techniques.

Conclusion: The canal wall-down technique is superior to the canal wall-up technique, especially for patients with cholesteatoma. Keywords: Chronic Disease; Otitis Media; Hearing Loss; Cholesteatoma, Middle Ear; Reoperation.

\section{INTRODUCTION}

Otitis media is defined as an inflammatory disease of the middle ear that may be infectious or not and focal or generalized. The course of disease may be acute with a tendency towards total resolution and a return to the integrity of the regions affected, or it may be chronic with permanent sequelae $(1,2,3)$.

Chronic otitis media (COM) is clinically characterized as an inflammatory condition associated with otorrhea and tympanic membrane perforation in some cases. The disease course is more than 3 months in duration and histopathologically it is associated with irreversible tissue changes.

The incidence of COM is higher in less developed countries. Malnutrition, poor hygiene, poor quality housing, and high population density are factors that are associated with a higher incidence of middle ear infections $(3,4)$.
COM can be subdivided into two groups: cholesteatomatous chronic otitis media (CCOM) and chronic otitis media without cholesteatoma (COMWC). A central or marginal perforation may be present. The inflammatory process in the middle ear mucosa may show different stages of evolution.

CCOM is characterized by epithelial accumulation with keratin production in the middle ear. Cholesteatoma may be classified as congenital or acquired, and is further categorized as primary or secondary cholesteatoma. Clinical and surgical treatments are available for COM. The first is reserved for COMWC when patient follow-up is possible. The surgical approach is suitable for both CCOM and COMWC and encompasses tympanoplasty, canal wall-up (CWU) and canal wall-down (CWD) mastoidectomy $(1,5,6)$ and its variations, including modified radical mastoidectomy or Bondy's procedure. The choice of technique remains controversial and is usually decided based on the presence or absence of cholesteatoma, its location, the state of the middle ear mucosa, and auditory thresholds. Recurrence and post-operative functional status vary between techniques. 
The aim of this study was to clarify which surgical technique provides the best outcomes in terms of disease control and improved hearing thresholds.

\section{METHOD}

This was a retrospective study of an historical cohort. The medical records of patients with COM who underwent a CWU or CWD mastoidectomy at the otorhinolaryngology department of a tertiary hospital between 1997 and 2005 were evaluated.

Postoperative outcomes for the 2 techniques mentioned above were compared using control of the disease, absence of otorrhea, and cholesteatoma recurrence during the follow-up period, which was at least 24 months, as criteria. Pure tone average hearing thresholds at $500 \mathrm{~Hz}$, $1000 \mathrm{~Hz}$, and $2000 \mathrm{~Hz}$ were also compared before and after surgery for both techniques.

Statistical analyses were performed using the Chi square test, and pvalues $<0.05$ were considered statistically significant.

Inclusion criteria: Patients of both sexes who were over 14 years of age, diagnosed with COM, had undergone a CWU or CWD mastoidectomy with preoperative and postoperative audiometry, and who were followed up for at least 2 years.

Exclusion criteria: Patients with sensorineural hearing loss, exposure to occupational noise, previous ear surgery, history of head trauma, or with a suspected perilymphatic fistula were excluded. The study was approved by the Ethics in Research Committee (number: 098/07).

\section{RESULTS}

A total of 88 patients ( 33 men and 55 women) were selected for the study. Their average age was 30 years (standard deviation, 15.17) with a minimum age of 14 and a maximum age of 78 . The average period of postoperative follow up of these patients was 7.5 years.

In the group of 39 patients with CCOM, 20 (51.3\%) had undergone a CWD mastoidectomy. Three (15\%) of these patients required a second surgery due to persistent otorrhea. Of the 19 (48.7\%) patients who underwent a CWU mastoidectomy, 11 (57.9\%) required a further operation, 8 due to the recurrence of a cholesteatoma and 3 due to persistent otorrhea.

Of the 49 individuals with COMWC, 8 (16.6\%) underwent a CWD mastoidectomy, and 2 (25\%) of these required a further operation due to persistent otorrhea. Of the $41(84.4 \%)$ patients who underwent a CWU mastoidectomy, 5(12.2\%) required further surgery, including 4 for persistent otorrhea and 1 due to the evolution of cholesteatoma.

When the CWU and CWD techniques were compared among the patients with CCOM, a higher rate of disease control and the absence of otorrhea and cholesteatoma were associated with the CWD technique $(\mathrm{p}<0.05)$.

There were no statistically significant pre- or postoperative differences in the pure tone average thresholds at $500 \mathrm{~Hz}, 1000 \mathrm{~Hz}$, and $2000 \mathrm{~Hz}$ between the techniques.

Table I. Disease control in patients with chronic otitis media with and without cholesteatoma according to surgical technique.

\begin{tabular}{cccc} 
Disease control & Total & RR $(95 \% \mathrm{Cl})$ \\
No & Yes & & \\
\hline
\end{tabular}

\begin{tabular}{lcccc}
\hline CCOM & & & & 0.25 (0.09-0.79)* \\
SurgicalTechnique & & & & \\
Canalwall-down & $3(15.0 \%)$ & $17(85.0 \%)$ & 20 & \\
Canalwall-up & $11(57.9 \%)$ & $8(41.1 \%)$ & 19 & \\
\hline TOTAL & $14(35.9 \%)$ & $25(64.1 \%)$ & 39 & \\
\hline COMWC & & & & $2.05(0.48-8.78)$ \\
SurgicalTechnique & & & 8 & \\
Canalwall-down & $2(25.0 \%)$ & $6(75.0 \%)$ & 41 & \\
Canalwall-up & $5(12.2 \%)$ & $36(87.8 \%)$ & 49 & \\
\hline TOTAL & $7(14.3 \%)$ & $42(85.7 \%)$ & 49 & \\
\hline
\end{tabular}

CCOM - Cholesteatomatous chronic otitis media; COMWC Chronic otitis media without cholesteatoma; RR - Relative Risk; 95\% CI - 95\% confidence interval; p value from the Chi-square test $<0.05$. 


\section{DISCUSSION}

Among the patients with COMWC, the disease control rate was $91.9 \%$, regardless of the technique used, which is similar to the rates reported in other studies, which have ranged from $63 \%$ to $96 \%(7,8,9,10)$. Among the patients with CCOM, the disease control rate was $64.1 \%$, which is slightly lower than previous reports, which have ranged from $75 \%$ to $90 \%(7,11,12,13)$.

When the CWU technique was used, the disease control rate for the first surgery was $76.6 \%$. In contrast, when the CWD technique was used, the disease control rate was $85.7 \%$, regardless of the presence of cholesteatoma. Data in the literature are similar with reported values ranging from $71 \%$ to $95 \%$ for the CWU technique $(9,11,14,15,16)$ and from $71 \%$ to $96 \%$ for the CWD technique $(9,11,13,14,15,16)$.

In the COMWC group, a higher rate of revision surgery was found among patients who underwent a CWD mastoidectomy (25\%) compared with a CWU mastoidectomy (12.2\%). This can be explained by the fact that patients with more severe disease were selected for CWD mastoidectomy.

Of the patients with CCOM who underwent a CWU mastoidectomy, $57.9 \%$ required revision surgery whereas only $15 \%$ of those who underwent a CWD mastoidectomy required revision surgery. The current literature also shows higher recurrence rates when patients with cholesteatoma undergo a CWU mastoidectomy. Cruz et al. (2001) reported surgical revision rates of $37.5 \%$ and $26.08 \%$ when using the CWU and CWD techniques, respectively. We believe that in our study the higher rate of reoperation observed when preserving the canal wall is related to the longer follow-up (median 7.5 years), and suggests late complications of the disease, which are not uncommon when the CWU technique is used.

The choice of technique remains controversial but this study, in agreement with the literature, has shown that cholesteatoma can be treated with the CWU technique. However, Bento et al. and Cruz et al. (14,5) suggest that criteria such as cholesteatoma restricted to the attic, good condition of the middle ear mucosa, and the possibility of good postoperative follow-up are required before the CWU technique is used.

In this study, no statistically significant difference in pure tone average thresholds before and after surgery with either of the techniques. Because patients with less than 2 years follow-up were excluded from the study, there was a considerable decrease in the number of individuals available for analysis, which hindered any robust analysis of this variable. In the literature we found many studies that reported better audiometric results when the CWU technique was used rather than the CWD technique $(7,8,10,11,15,17)$. However, other studies have reported no significant differences in hearing outcomes in association with the two techniques (16).

\section{CONCLUSION}

The CWD technique and its various modifications results in better outcomes, especially when it comes to surgery to control CCOM. Some precautions facilitate a satisfactory functional outcome with better control of persistent otorrhea and greater certainty as to the eradication of cholesteatoma compared to CWU mastoidectomy.

\section{REFERENCES}

1. Costa SS, Dornelles CC, Netto LFS, Braga MEL. Aspectos gerais das otites médias. In: Costa SS, Cruz OLM, Oliveira JAA. Otorrinolaringologia Princípios e Prática. 2nd ed. São Paulo: Artmed; 2006. p. 254-73.

2. Bluestone CD. Epidemiology and pathogenesis of chronicsuppurative otitismedia: implications for prevention and treatment. Int J Pediatr Otorhinolaryngol. 1998 Jan;420:207-23.

3. Azevedo AF, Pinto DCG, Souza NJA, Greco DB, Gonçalves DU. Perda auditiva sensório-neural na otite média crônica supurativa em pacientes com e sem colesteatoma. Braz J Otorhinolaryngol. 2007 Sep-Oct;73(5):671-4.

4. Godinho RN, Goncalves TM, Nunes FB, et al. Prevalence and impact of chronicotitismedia in school age children in Brazil. First epidemiologic study concerning chronicotitismedia in Latin America. Int J Pediatr Otorhinolaryngol. 2001 Dec;61(3):223-32.

5. Cruz OLM, Campos CAH. Cirurgia para a otite média crônica. Acta Otorrinolaringol. 2005;23(1):33-8.

6. Roland PS, Isaacson B, Kutz JW. Office management of tympanic membrane perforation and the draining ear. In: Brackmann DE, Shelton C, Arriaga MA. Otologic Surgery. 3rd ed. Philadelphia: Saunders Elsevier; 2010. p. 107-18.

7. Segalla DK, Nakao LH, Anjos MF, Penido NO. Resultados cirúrgicos e audiológicos pós mastoidectomia emum serviço de Residência Médica. Acta Otorrinolaringol. 2008;26(3):178-81. 
8. Vartianinen E, Nuutinen J. Long term hearing results of one stage tympanoplasty for chronic otitis media. Eur Arch Otorhinolaryngol. 1992;249(6):329-31.

9. Veldman JE, Braunius WW. Revision surgery for chronic otitis media: a learning experience. Report on 389 cases with a long-term follow-up. Ann Otol Rhinol Laryngol. 1998 Jun;107(6):486-91.

10. Cruz OL, Kasse CA, Leonhart FD. Efficacy of surgical treatment of chronic otitis media. Otolaryngol Head Neck Surg. 2003 Feb;128(2):263-6.

11. Cruz OLM, KasseCA, Leonhardt FD. Eficácia do tratamento cirurgico da otite média crônica colesteatomatosa. Braz J Otorhinolaryngol. 2001 Mar-Apr;67(2):142-6.

12. CookJA, Krishnan S, Fagan PA. Hearing results following modified radical versus canalup mastoidectomy. Ann Otol Rhinol Laryngol. 1996 May;105(5):379-83.
13. Chang CC, Chen MK. Canal-wall-down tympanoplasty with mastoidectomy for advanced cholesteatoma. J Otolaryngol. 2000 Oct;29(5):270-3.

14. Bento RF, Rezende VA, Soares IP. Mastoidectomia: Estado atual da indicação cirúrgica do ponto de vista infeccioso. Braz J of Otorhinolaryngol. 2004 Apr-Jun;60(2):98-102.

15. Harkness P, Brown P, Fowler S, Grant H, Ryan R, Topham J. Mastoidectomy audit: results of the Royal College of Surgeons of England comparative audit of ENT surgery. Clin Otolaryngol Allied Sci. 1995 Feb;20(1):89-94.

16.Zhang X, Chen Y, Liu Q, Han Z, Xu A, Ding Y. Long-term results analysis of mastoidectomy for chronic otitis media. Lin Chuang Er Bi Yan Hou Ke Za Zhi. 2005 Oct;19(19):870-2.

17. Murphy TP, Wallis DL. Hearing results in pediatric patients after canal-wall-up and canal-wall-down mastoid surgery. Otolaryngol Head Neck Surg. 1998 Nov;119(5):439-43. 